\title{
PROFIL STRATEGI PEMBELAJARAN BAHASA JEPANG DI SMP NEGERI 1 UBUD
}

\author{
N.P.E.R.Diana ${ }^{1}$ D.M.S.Mardani ${ }^{2}$ I.W.Sadyana ${ }^{3}$ \\ 123 Jurusan Pendidikan Bahasa Jepang, Universitas Pendidikan Ganesha, Singaraja,Bali \\ e-mail: : : erarenovati@gmail.com \\ desak.mardani@undiksha.ac.id wayan.sadyana@undiksha.ac.id
}

\begin{abstract}
Abstrak
Penelitian ini bertujuan untuk mengetahui (1) Untuk mendeskripsikan strategi yang digunakan dalam mengajar bahasa Jepang di SMP Negeri 1 Ubud, (2) Untuk mengetahui faktor-faktor yang mendasari penggunaan strategi pembelajaran dalam proses pembelajaran bahasa Jepang di SMP Negeri 1 Ubud, (3) Untuk mengetahui kendala-kendala apa saja yang dihadapi guru di SMP Negeri 1 Ubud. Pengumpulan data dilakukan dengan metode observasi, wawancara, dan dokumentasi kemudian dianalisis dengan metode deskriptif kualitatif. Hasil penelitian menunjukkan bahwa (1) penerapan strategi yang digunakan oleh guru SMP Negeri 1 Ubud adalah strategi drill dan tanya jawab. Didalam proses belajar mengajar guru banyak memberikan latihan-latihan pada pelatihan kosakata di dalam kelas yang dilakukan dengan latihan drill menggunakan media gambar. Strategi tanya jawab ini digunakan oleh guru pada saat bertanya kepada siswa untuk mendapatkan respon siswa terkait materi yang diberikan. Proses tanya jawab ini dimulai oleh guru untuk memancing pertanyaan dari siswa, (2) guru bahasa Jepang di SMP Negeri 1 Ubud menggunakan strategi pembelajaran berdasarkan karakteristik siswa, keadaan siswa di kelas, kesiapan siswa dan perangkat pembelajaran (3) Kendala yang dihadapi dalam pembelajaran bahasa Jepang adalah fasilitas sarana dan prasarana, pengelolaan kelas dan penggunaan strategi pembelajaran.
\end{abstract}

Kata kunci : Profil, Strategi Pembelajaran, Kendala

\section{要旨}

本研究の目的は、（1）公立ウブド第一中学校の日本語学習ストラテジーについ て、（2）同校の日本語学習過程において学習ストラテジーが用いられる要因、

（3）同校日本語指導教師が直面する問題点を明らかにすることである。データは、 授業観察、インタビュー、撮影記録により収集し、それを定性的記述法により分析 した。結果、（1）公立ウブド第一中学校の日本語指導教師は、ドリル演習及び質疑 応答による学習ストラテジーを実施している。ドリル演習においては、絵教材を使 用し単語練習を多く取り入れている。質疑応答においては、与えられた授業内容に 即した教材に関して、教師が生徒に質問することにより生徒たちの反応を見、生徒 達からの質問を促している。（2）同校日本語指導教師は、生徒の特性、クラスの状 況、生徒たちの準備状態、学習材料により学習ストラテジーを決定している。

同校日本語指導教師が抱える問題点として、設備などの学習環境、教室管理、学習 ストラテジーの選択が挙げられる。

キーワード:紹介、学習ストラテジー、問題点 


\section{Pendahuluan}

Menurut Cahyadiantari (2017) strategi pembelajaran adalah kegiatan pembelajaran tertentu yang dipilih guru untuk melakukan program pembelajaran yang memungkinkan siswa melakukan proses pembelajaran secara optimal untuk mencapai tujuan pembelajaran. Dengan adanya strategi pembelajaran maka proses pembelajaran akan terarah dan efektif. Sehingga guru memiliki pedoman dan acuan dalam proses pembelajaran. Guru diharapkan memiliki kemampuan untuk memilih strategi yang tepat dalam melaksanakan proses pembelajaran. Dengan begitu seorang guru akan mampu meningkatkan minat belajar siswa dalam pembelajaran bahasa Jepang.

Dalam belajar bidang studi pasti memerlukan strategi pembelajaran, hal ini termasuk juga belajar bahasa asing seperti bahasa Jepang. Bahasa Jepang merupakan salah satu bahasa asing yang di ajar di SMA/SMK, namun dari hasil observasi yang dilakukan di sekolah-sekolah pembelajaran bahasa Jepang juga diajarkan di Sekolah Menengah Pertama terutama di daerah Kecamatan Ubud. Ditemukan bahwa pembelajaran bahasa asing yang diberikan di SMP Negeri 1 Ubud tidak hanya bahasa Inggris saja namun juga memberikan bahasa Jepang. Di SMP Negeri 1 Ubud lebih menekankan siswa untuk bisa berkomunikasi menggunakan bahasa Jepang. SMP Negeri 1 Ubud ini merupakan sekolah menengah pertama dan satu-satunya di daerah Ubud yang memberikan pembelajaran bahasa Jepang. Sekolah ini sudah memberikan pembelajaran bahasa Jepang sejak tahun 2004.

Berdasarkan wawancara awal yang dilakukan terhadap beberapa siswa di SMP Negeri 1 Ubud diketahui bahwa guru bahasa Jepang sudah menerapkan strategi mengajar. Ada beberapa strategi guru yang diterapkan dalam proses pembelajaran di kelas. Strategi yang digunakan oleh guru tersebut tentunya mampu membantu siswa lebih mudah mengerti dengan materi yang diajarkan. Strategi yang digunakan ini pula dianggap sangat cocok diterapkan untuk siswa yang ada di SMP Negeri 1 Ubud. Mengingat siswa masih tergolong pebelajar bahasa Jepang pemula, sehingga dari penelitian ini diharapkan kita dapat mengetahui bahwa pentingnya balajar bahasa Jepang ditingkat pemula agar memudahkan siswa belajar bahasa Jepang ditingkat SMA.

Penelitian mengenai profil strategi pembelajaran sudah pernah dilakukan oleh Dewi (2015) dan Yastini (2015) penelitian tersebut dirancang dalam bentuk penelitian deskriptifkualitatif.

Penelitian ini memberikan gambaran yang berkaitan dengan proses pembelajaran di SMP Negeri 1 Ubud meliputi penggunaan strategi, media, pemilihan bahan ajar dan kendala yang ditemui pada proses pembelajaran dan cara guru mengatasi kendala tersebut.

Berdasarkan pemaparan di atas, penulis bermaksud untuk melaksanakan penelitian mengenai strategi pembelajaran yang digunakan oleh guru bahasa Jepang di SMP Negeri 1 Ubud yang penulis tuangkan dalam penelitian dengan judul "PROFIL STRATEGI PEMBELAJARAN BAHASA JEPANG DI SMP NEGERI 1 UBUD".

Berdasarkan latar belakang yang telah dipaparkan, maka dapat dirumuskan permasalahan adalah sebagai berikut :

1. Bagaimana penerapan strategi yang digunakan oleh guru bahasa Jepang di SMP Negeri 1 Ubud?

2. Faktor-faktor apa saja yang mendasari penggunaan strategi pembelajaran tersebut dalam proses pembelajaran Bahasa Jepang di SMP Negeri 1 Ubud?

3. Kendala-kendala apa saja yang dihadapi guru di SMP Negeri 1 Ubud?

\section{Teori Pembelajaran Bahasa Jepang Dasar}

Pembelajaran bahasa Jepang dasar yaitu pembelajaran yang mengajarkan hal-hal dasar dari bahasa Jepang, seperti huruf, lafal, kosa kata, yang sesuai dengan situasinya. Menurut Matsumoto (2007) ada tiga tahapan dalam proses pembelajaran bahasa Jepang dasar yaitu Dounyuu (導入) atau pengenalan, yang kedua Kihon renshuu (基本練習) atau latihan dasar, yang ketiga Ouyou renshuu ( 応用練習) atau latihan penerapan. Ketiga 
tahapan ini sangat berpengaruh terhadap berhasilnya proses pembelajaran bahasa Jepang dasar di kelas.

\section{Metode Pembelajaran}

Padmadewi (2012:19-83) memberikan 6 Metode Pembelajaran Bahasa diantaranya : Grammar Translation Metode (GTM), Direct Method, Audiolingual Method, Total Physical Response (TPR), Community Language Learning (CLL) dan Communicative Language Teaching (CLT).

1. Grammar Translation Metode (GTM) adalah metode yang menekankan pada guru sebagai pemegang otoritas di dalam kelas. Seperti nama metode ini, siswa diberikan penjelasan mengenai tata bahasa target, diberikan latihan-latihan pembuatan kalimat yang diterjemahkan dari bahasa pertama ke bahasa target atau sebaliknya.

2. Direct Method adalah metode yang tidak menggunakan bahasa ibu sebagai bahasa pengantar dan tidak menggunakan terjemahan. Direct Method memiliki tujuan yang sangat berbeda. Tujuan pembelajaran siswa diarahkan untuk bagaimana siswa bisa menggunakan bahasa asing dalam berkomunikasi

3. Audiolingual Method adalah metode yang memberikan penekanan pada pencapaian kemampuan berkomunikasi secara lisan dalam bahasa target.

4. Total Physical Response (TPR) metode yang menekankan pada pentingnya mempertimbangkan factor afektif/emosional siswa. Dengan metode ini, siswa belajar bahasa dengan lebih banyak merespon dengan gerakan sehingga belum menuntut siswa untuk mampu merespon secara linguistik.

5. Community Language Learning (CLL) merupakan metode yang mempunyai konsep pembelajaran yang menganjurkan agar guru memperlakukan siswanya sebagai seorang pribadi yang utuh yang tidak hanya memperhatikan kemampuan intelektual siswa tetapi juga memperhatikan perasaaan siswa, kenyamanan siswa, dan keinginannya untuk belajar dan tidak membiarkan timbulnya rasa takut dan stress ketika belajar di dalam kelas.

6. Communicative Language Teaching (CLT) adalah metode yang muncul karena adanya reaksi terhadap proses pembelajaran bahasa target sebelumnya yaitu dominasi penggunaan unsur tata bahasa dalam pembelajaran struktural -situasional dan penekanan penggunaan strategi pembelajaran berbasis "Drill".

\section{Jenis-Jenis Strategi Pembelajaran}

1. Diskusi

Diskusi merupakan kegiatan saling menukar informasi bertujuan untuk memecahkan masalah, menjawab suatu pertanyaan, dan mempercepat suatu pemahaman atar peserta dalam kelompok.

Destiari (2017) menambahkan metode diskusi merupakan salah satu cara mendidik yang berupaya memecahkan masalah yang dihadapi, baik dua orang atau lebih yang masing-masing mengajukan argumentasinya untuk memperkuat pendapatnya.

Strategi diskusi ini digunakan ketika guru bermaksud untuk melatih siswa dalam berkomunikasi seperti halnya siswa mengungkapkan ide dengan jelas, agar siswa dapat berpikir kritis tentang sebuah topik yang diajarkan, dan mengetahui sejauh mana siswa mengetahui ide dan pemahaman antar siswa sehingga mereka menggunakan pemicu untuk pembelajaran lebih lanjut.

2. Kerja Kelompok Kecil

Kerja kelompok diartikan siswa dikelompokkan lebih dari dua orang siswa untuk bekerjasama dengan anggota yang bervariasi. Kerja kelompok sama halnya dengan diskusi, dalam kerja kelompok akan memperoleh hasil belajar yang berbeda-beda tergantung pada masukan masing-masing siswa, jika tidak dipersiapkan dengan baik maka sulit untuk mencapai hasil belajar (Padmadewi,2012).

Untuk memperoleh hasil yang maksimal, guru harus mempertimbangkan strategi mengajar yang tepat dilihat dari siswa dan materi yang akan diberikan. Situasi yang memungkinkan untuk kerja kelompok yaitu ketika guru menginginkan siswa saling belajar bertukar informasi, meningkatkan pemahaman siswa terhadap materi, meningkatkan 
motivasi, dan meningkatkan keterampilan siswa dalam menemukan solusi dan memecahkan suatu masalah.

3. Aktivitas Kinerja

Aktivitas kinerja adalah strategi pengajaran yang dilakukan oleh siswa berupa peran seperti aktivitas formal (drama dengan scenario), aktivitas terstruktur (seperti debat), aktivitas bebas (role play) atau dalam bentuk permainan simulasi (Padmadewi, 2012).

4. Menggunakan Lagu dan Permainan

Strategi pembelajaran bahasa menggunakan lagu dan permainan memerlukan kreatifitas guru untuk melakukan inovasi dalam pembelajaran (Padmadewi, 2012:171). Dengan menggunakan lagu dan permainan akan menjadi perubahan pembelajaran ke arah yang lebih menyenangkan dan menghidupkan suasana belajar di dalam kelas.

5. Kooperatif

Putri (2016) menyatakan bahwa pembelajaran kooperatif merupakan bentuk pelajaran dengan cara siswa belajar dalam kelompok. Setiap anggota kelompok masingmasing anggotanya yang terdiri dari 4-6 orang dengan struktur kelompok yang besifat heterogen.

Attle dan Baker (2007) menambahkan bahwa pembelajaran kooperatif yaitu teknik pembelajaran yang penerapannya mendorong siswa untuk bekerja bersama dalam meningkatkan pembelajarannya sendiri dan pembelajaran dengan teman sejawatnya.

Jadi strategi ini lebih menekankan pada kerja sama antar siswa didalam suatu kelompok yang dapat mendorong siswa untuk berfikir, memecahkan masalah, dan menghubungkan pengetahuan dengan keterampilan.

6. Drill

Anitah (2009) menambahkan strategi lainnya yaitu drill atau latihan sebagai salah satu bagian dari jenis-jenis strategi pembelajaran. Drill atau latihan adalah strategi pembelajaran yang memberikan sebuah latihan agar siswa memperoleh suatu keterampilan tertentu.

Yani (2016) menambahkan strategi drill diartikan sebagai cara mengajar dengan melakukan kegiatan secara berulang kali agar siswa dapat mengingat lebih lama apa yang telah dipelajari. Strategi ini dapat membantu siswa dalam mengembangkan kemampuannya. 7. Tanya Jawab

Selanjutnya Roestiyah (2001) menambahkan strategi tanya jawab. Strategi tanya jawab adalah suatu teknik atau strategi mengajar dalam tujuan untuk memberikan motivasi kepada siswa agar terlatih untuk bertanya. Direktorat Tenaga Kependidikan (2008) menyatakan bahwa dengan strategi tanya jawab dalam mengajar memungkinkan terjadinya komunikasi langsung antara guru dan siswa.

\section{Memilih Strategi Mengajar yang Tepat}

Menurut Padmadewi (2012) untuk memperoleh hasil pembelajaran sesuai dengan tujuan pembelajaran, perlu diadakan pemilihan strategi yang tepat. Seorang guru harus mengetahui strategi-strategi pembelajaran dan menerapkannya dengan baik. Dengan begitu seorang guru akan berhasil dalam kegiatan belajar.

\section{Kendala Dalam Pengajaran}

Menurut Slameto (2003), pengajaran oleh guru harus dapat merencanakan, mendesain, mempersiapkan, melaksanakan, dan mengevaluasi kegiatan-kegiatan pembelajaran secara efektif dalam jangka waktu yang layak.

Dimyati, dkk (2002) menambahkan bahwa berhasilnya suatu tujuan pembelajaran dilihat dari bagaimana proses belajar mengajar yang dialami oleh siswa dan seorang guru dituntut untuk teliti dalam memilih dan menerapkan strategi mengajar yang sesuai dengan tujuan yang ingin dicapai.

\section{Metode}

\section{Metode dan Teknik Pengumpulan Data}


Pada penelitian ini, proses pengumpulan datanya menggunakan metode metode observasi, wawancara dan dokumentasi.

Metode Observasi digunakan untuk melihat secara langsung, mengamati, dan mencermati proses maupun keadaan yang ada pada objek penelitian yaitu SMP Negeri 1 Ubud. Observasi ini dilakukan di SMP Negeri 1 Ubud, untuk mengamati pelaksanaan pembelajarannya yang menyangkut seluruh proses pembelajarannya.

Metode interview (wawancara) digunakan untuk sebagai acuan dalam melakukan wawancara langsung untuk memperoleh data tentang profil proses pembelajaran SMP Negeri 1 Ubud. Dalam hal ini, peneliti melakukan wawancara untuk mempertegas hasil yang telah diperoleh melalui observasi.

Dalam metode dokumentasi ini penulis mendokumentasikan foto-foto proses pembelajaran di SMP Negeri 1 Ubud. Proses ini dimulai dari proses awal pembelajaran sampai akhir pemebelajaran berlangsung. Selain itu, penulis akan menggunakan metode ini untuk mengumpulkan data secara tertulis yang bersifat dokumenter seperti : dokumen yang terkait dengan administrasi pembelajaran (RPP, media pembelajaran,dll).

\section{Metode dan Teknik Analisis Data}

Metode dan teknik analisis data pada penelitian ini dilakukan secara deskriptifkualitatif untuk data strategi dan metode yang digunakan dalam SMP Negeri 1 Ubud. Analisis data dalam penelitian ini mengikuti prosedur: 1) tabulasi data; 2) reduksi data; 3) deskripsi data, 4) klasifikasi data, dan 5) penarikan kesimpulan.

Pada tahapan reduksi data ini, data hasil observasi, wawancara dan dokumentasi akan digabungkan dan diklasifikasikan berdasarkan judul penelitian yaitu profil strategi pembelajaran bahasa Jepang.

Reduksi data dilakukan dengan reduksi data dilakukan dengan penyederhanaan data yang diperoleh dari hasil observasi dan wawancara terhadap guru di SMP Negeri 1 Ubud.

Pada tahap deskripsi data, seluruh data yang diperoleh melalui observasi dan wawancara dideskripsikan sesuai dengan kenyataan yang ada di lapangan, yang dibuat secara fakta. Pendeskripsian ini dilakukan berdasarkan sub masalah yang telah dikemukakan dalam rumusan masalah. Kemudian pada tahap klasifikasi data yaitu proses pengelompokan suatu unsur dari data yang sudah tersusun rapi menjadi data yang tersusun berdasarkan ketegori-kategori tertentu, sesuai dengan tujuan penelitian. Pada klasifikasi data tergambar secara garis besar sebagai berikut.

1. Profil penerapan strategi mengajar guru bahasa Jepang di SMP Negeri 1 Ubud.

2. Faktor-faktor yang mendasari penggunaan strategi pembelajaran dalam proses pembelajaran bahasa Jepang di SMP Negeri 1 Ubud.

3. Kendala-kendala yang dihadapi serta solusi menghadapi kendala-kendala tersebut dalam pembelajaran bahasa Jepang di SMP Negeri 1 Ubud.

\section{Hasil Dan Pembahasan Data Hasil Observasi Penelitian}

Dalam penelitian ini observasi dilakukan dalam kegiatan proses pembelajaran bahasa Jepang yang terapat di SMP Negeri 1 Ubud. Observasi dilakukan sebanyak empat kali, dengan guru bahasa Jepang sebagai subjek penelitian. Hal-hal yang diamati pada proses observasi antara lain penerapan strategi pembelajaran yang digunakanan guru dalam mengajar, media pembelajaran yang digunakan oleh guru sebagai sarana penunjang dalam kegiatan pembelajaran dan kendala-kendala yang dihadapi oleh guru pada pembelajaran bahasa Jepang.

Data yang diperoleh pada observasi pertama yaitu, guru mengajarkan materi Keluarga Orang Lain. Guru mengajarkan materi tersebut dengan menggunakan strategi pembelajaran yaitu strategi drill dan tanya jawab. Media pembelajaran yang digunakan yaitu kartu bergambar. Proses Latihan drill dilakukan oleh seluruh siswa, latihan drill yang pertama dilakukan oleh seluruh siswa (guru dan seluruh siswa), latihan drill yang kedua dilakukan 
oleh kelompok siswa (guru dan kelompok siswa). Guru memperlihatkan gambar lalu siswa menjawab dengan bahasa Jepang.

Data yang diperoleh pada observasi kedua yaitu, guru mengajarkan materi Usia dan Pekerjaan. Guru mengajarkan materi tersebut dengan menggunakan strategi pembelajaran yaitu strategi drill dan tanya jawab. Media pembelajaran yang digunakan yaitu kartu bergambar. Di dalam proses pembelajaran di kelas hanya menggunakan strategi drill dan tanya jawab saja, dikarenakan waktu mengajar yang sangat singkat. Pada proses latihan drill guru memperlihatkan gambar lalu siswa menjawab dengan bahasa Jepang.

Data yang diperoleh pada observasi ketiga yaitu, guru kembali melanjutkan materi yang diajarkan sebelumnya dikarekanan alokasi waktu yang disediakan yakni hanya satu jam pelajaran dianggap kurang efektif dalam mengajarkan materi Usia dan Pekerjaan. Guru mengajarkan materi tersebut dengan menggunakan strategi pembelajaran yaitu strategi drill dan tanya jawab. Media pembelajaran yang digunakan yaitu kartu bergambar. Pada proses latihan drill guru memperlihatkan gambar lalu siswa menjawab dengan bahasa Jepang. pada saat memberikan tanya jawab siswa satu persatu kedepan kelas untuk melakukan tanya jawab dengan temannya untuk mengetahui sejauh mana siswa mengetahui materi yang diberikan.

Data yang diperoleh pada observasi keempat yaitu, guru mengajarkan materi Sifat dan Gambaran Fisik. Guru mengajarkan materi tersebut dengan menggunakan strategi pembelajaran yaitu strategi drill dan tanya jawab. Media pembelajaran yang digunakan yaitu kartu bergambar. Buku penunjang yang digunakan pada saat proses pembelajaran yaitu Buku penunjang dalam bentuk LKS.

\section{Data Hasil Wawancara}

Berdasarkan hasil wawancara dengan guru bahasa Jepang di SMP Negeri 1 Ubud, pembelajaran bahasa Jepang ini sudah berdiri dari tahun 2004. Dalam pembelajaran di SMP Negeri 1 Ubud ini dilaksanakan setiap hari senin sampai hari jumat yaitu total waktu sekitar 10 jam. Buku penunjang yang digunakan adalah LKS "Buku Pendamping Materi Bahasa Jepang" dan Buku Sakura. Media yang digunakan dalam pembelajaran bahasa Jepang yaitu papan tulis dan kartu bergambar.

Pembelajaran bahasa Jepang yang dilaksanakan di SMP Negeri 1 Ubud ini lebih berfokus menggunakan bahasa Jepang dasar. Materi yang diajarkan lebih dipersempit dari pembelajaran yang diberikan di Sekolah Menengah Atas. Waktu pembelajaran juga sangat sedikit yaitu 1 jam pelajaran. Pada saat proses pembelajaran, guru menjelaskan materi menggunakan bahasa Indonesia. Jika guru menggunakan bahasa Jepang siswa tidak mengerti sama sekali dan mereka cenderung lebih cepat bosan belajar karena mereka tidak mengerti apa yang jelaskan oleh guru.

Dalam pembelajaran bahasa Jepang dasar terdapat tiga jenis tahapan pembelajaran bahasa Jepang yaitu yang pertama 導入(Dounyuu/atihan pengenalan) latihan tentang kemampuan pemahaman, yang kedua 基本練習 (Kihon renshuu/latian dasar) latihan tentang mengingat, kemudian yang ketiga 応用練習 (Ouyou renshuu/atihan penerapan) latihan tentang menggunakan bahasa Jepang.

Tahap pertama guru menggunakan 導入(Dounyuu/atihan pengenalan) dengan menggunakan bahasa ibu pelajar (bahasa Indonesia). Tahap kedua, proses dilanjutkan dengan基本練習 (Kihon renshuu/latian dasar dalam hal ini guru juga sering terlihat memberikan drill sebagai latihan dasar. Kemudian tahap ketiga yakni応用練習 (Ouyou renshuu/atihan penerapan) guru menggunakan latihan tanya jawab dan percakapan antara siswa dengan siswa.

Strategi yang digunakan oleh guru bahasa Jepang di SMP Negeri 1 Ubud adalah strategi drill dan tanya jawab. Faktor yang dijadikan acuan dalam penerapan strategi mengajar guru adalah karakteristik siswa yang merupakan hal utama guru menggunakan strategi drill dan tanya jawab dalam proses pembelajaran, karena jika dilihat dari minat siswa dalam belajar bahasa asing, khususnya dalam belajar bahasa Jepang masih kurang. Dari 
karakter siswa, guru menggunakan strategi drill dan tanya jawab untuk melatih pemahaman kosakata serta pola kalimat.

Kendala yang dihadapi dalam pembelajaran bahasa Jepang adalah minat belajar siswa yang sangat sedikit. Jadi guru kesulitan untuk melanjutkan ke materi selanjutnya. Minat belajar mereka di rumah sangat sedikit. Selain itu, waktu yang diberikan sangat sedikit, sarana dan prasarana yang kurang mendukung serta media pembelajaran yang terbatas.

Berdasarkan hasil observasi dan hasil wawancara, pembelajaran bahasa Jepang di SMPNegeri 1 Ubud adalah sebagai berikut.

\section{A. Penerapan strategi yang digunakan dalam proses pembelajaran}

Dilihat dari langkah-langkah pembelajaran pembelajaran bahasa Jepang dasar terdapat tiga jenis tahapan pembelajaran bahasa Jepang yaitu yang pertama 導入 (Dounyuu/atihan pengenalan) latihan tentang kemampuan pemahaman, yang kedua 基本練習 (Kihon renshuu/latian dasar) latihan tentang mengingat, kemudian yang ketiga 応用練習 (Ouyou renshuu/atihan penerapan) latihan tentang menggunakan bahasa Jepang. Tahap pertama 導入 (Dounyuu/atihan pengenalan) dengan menggunakan bahasa ibu pelajar (bahasa Indonesia). Pada tahap ini guru memberikan mengulang materi pada pertemuan sebelumnya. Tahap kedua, proses dilanjutkan dengan 基本練習 (Kihon renshuu/latian dasar) yang dilatihkan yaitu 反復練習 (Hanpukurenshuul latihan pengulangan) dan 応答練習 (Outourenshuu/latihan kegiatan menjawab dan merespons). Pada latihan pengulangan (Hanpukurenshuu) guru juga sering terlihat memberikan drill sebagai latihan dasar.

Drill tersebut dilakukan pada kegiatan mengamati. Pada kegiatan mengamati, guru menggunakan media gambar dan siswa mengamati gambar yang diperlihatkan oleh guru. Siswa mengamati media gambar yang diajukan oleh guru utamanya dalam latihan kosakata. Guru juga memberikan latihan cara pengucapan dan bunyi panjang dan pendek pada kosakata tersebut secara berulang-ulang dengan cara menyebutkan kosakata menggunakan bahasa Jepang kemudian siswa mengikutinya.

Latihan dilakukan oleh seluruh siswa, latihan drill yang pertama dilakukan oleh seluruh siswa (guru dan seluruh siswa), latihan drill yang kedua dilakukan oleh kelompok siswa (guru dan kelompok siswa).

Guru banyak memberikan latihan-latihan pada pelatihan kosakata di dalam kelas yang dilakukan dengan latihan drill menggunakan media gambar. Dengan menggunakan media gambar tersebut siswa dituntut untuk mampu perpikir dan menebak kosakata yang diwakili oleh gambar. Media gambar juga mampu membantu siswa lebih mudah mengingat kosakata yang diberikan.

Selain strategi drill guru juga menggunakan strategi tanya jawab didalam kegiatan基 本練習 (Kihon renshuu/latian dasar) yang dilatihkan yaitu応答練習 (Outourenshuu/latihan kegiatan menjawab dan merespons). Berdasarkan observasi yang telah dilakukan, penggunaan strategi tanya jawab terlihat dalam semua observasi yang ada dalam pembelajaran bahasa Jepang di setiap kelas.

Tahap ketiga yakni 応用練習 (Ouyou renshuu/atihan penerapan) pada kegiatan ini seluruh siswa melakukan tanya jawab antara teman sebangku didepan kelas untuk mengetahui apakah siswa sudah paham tentang pola kalimat yang telah dipelajari.

\section{B. Faktor Yang Dijadikan Acuan Dalam Penerapan Strategi Mengajar Guru}

1. Karakteristik Siswa

Karakteristik siswa sekolah menengah pertama yang cenderung cepat bosan dalam mengikuti pembelajaran dan sering bercanda dengan temannya ketika guru menjelaskan pelajaran merupakan faktor utama guru dalam menggunakan strategi drill dan tanya jawab dalam proses pembelajaran. Jika dilihat dari minat siswa dalam belajar bahasa Asing, khususnya dalam belajar bahasa Jepang masih kurang, ini disebabkan karena pembelajaran bahasa Jepang baru diajarkan di awal, yaitu pada tingkat sekolah menengah pertama ( SMP ).

2. Keadaan Siswa di Kelas 
Strategi drill, dan tanya jawab digunakan agar siswa dapat berperan aktif dalam proses pembelajaran, tidak hanya seorang guru saja yang berperan melainkan keikutsertaan siswa dalam proses pembelajaran akan menciptakan pembelajaran yang sesuai.

3. Kesiapan Siswa

Kesiapan siswa dalam mengikuti pelajaran juga merupakan faktor ketiga guru menggunakan strategi dalam proses pembelajaran di kelas. Terlihat dari siswa malasnya mengerjakan pekerjaan rumah (PR) dan salah satu siswa buku LKS yang ketinggalan dirumah. Untuk itu guru menerapkan strategi drill dan tanya jawab agar lebih mudah mengetahui kesiapan siswa dalam proses pembelajaran bahasa Jepang. Terlihat disetiap observasi guru melakukan drill diawal pembelajaran agar siswa mengingat materi sebelumnya dan siap untuk mengikuti materi pelajaran berikutnya.

4. Perangkat Pembelajaran/Media

Perangkat pembelajaran juga merupakan faktor keempat guru menggunakan strategi dalam proses pembelajaran di kelas. Dalam proses pembelajaran dikelas guru hanya menggunakan media gambar. Disetiap pertemuan guru menggunakan strategi drill dengan media gambar agar siswa lebih bersemangat mengikuti pembelajaran dan tidak cepat bosan belajar bahasa Jepang dikelas. Guru menggunakan media gambar ini untuk membantu siswa dalam mengingat kosakata yang dipelajari.

\section{Kendala-kendala Yang Dihadapi Guru Dalam Mengajar Bahasa Jepang}

1. Fasilitas sarana dan prasarana

Fasilitas sarana dan prasarana merupakan kendala yang dihadapi oleh guru bahasa Jepang di SMP Negeri 1 Ubud dimana fasilitas yang digunakan seperti LCD yang kurang mendukung. Untuk melaksanakan proses pembelajaran bahasa, terutama dalam pembelajaran bahasa asing, diperlukan sebuah media pembelajaran. Apabila hanya menggunakan ceramah saja dan hanya menggunakan media gambar, pembelajaran akan bersifat monoton serta kurang inovatif. Sehingga perlu adanya sesuatu yang nyata berupa video pembelajaran.

2. Kendala dalam Pengelolaan Kelas

Guru kurang tegas dalam mengatur atau mengelola kelas. Hal itu terlihat ketika siswa diperintahkan untuk membuat dialog sederhana beberapa siswa terlihat masih ada yang bercanda tidak menghiraukan perintah dari guru. Hal itu karena perintah guru kurang jelas dan kurang tegas, sehingga siswa tidak menanggapi secara serius instruksi yang diberikan oleh guru.

3. Kendala dalam Penggunaan Strategi

Dalam pembelajaran bahasa Jepang, variasi strategi yang diterapkan oleh guru masih sangat kurang. Salah satu strategi yang dapat dicoba adalah strategi permainan. Karena pembelajaran akan lebih menyenangkan apabila pada memberikan permainan dalam proses pembelajaran. Siswa akan lebih bersemangat dalam mempelajari materi diberikan.

\section{Simpulan dan Saran}

Berdasarkan hasil penelitian dan pembahasan mengenai profil pembelajaran bahasa Jepang di SMP Negeri 1 Ubud dapat disimpulkan sebagai berikut.

Pembelajaran bahasa Jepang yang ada di SMP Negeri 1 Ubud di dalam proses pembelajaran guru menerapkan strategi drill dan tanya jawab. Berdasarkan penggunaan strategi tersebut didasari atas empat faktor yakni karakteristik siswa, keadaan siswa di kelas, kesiapan siswa dan perangkat pembelajaran. Didalam proses pembelajaran guru menggunakan kartu bergambar agar siswa tidak bosan mengikuti pembelajaran bahasa Jepang.

Kendala-kendala yang dihadapi guru dalam proses pembelajaram bahasa Jepang antara lain fasilitas sarana dan prasarana yang kurang mendukung seperti fasilitas LCD yang kurang mendukung. Media yang digunakan hanya media gambar saja terkait dengan materi yang dijelaskan.Kendala dalam Pengelolaan Kelas guru kurang tegas dalam 
mengatur atau mengelola kelas. Hal itu terlihat ketika siswa diperintahkan untuk membuat dialog sederhana beberapa siswa terlihat masih ada yang bercanda tidak menghiraukan perintah dari guru. Kendala dalam Penggunaan Strategi dalam pembelajaran bahasa Jepang, variasi strategi yang diterapkan oleh guru masih sangat kurang. Salah satu strategi yang dapat dicoba adalah strategi permainan.

Dengan adanya penelitian mengenai profil pembelajaran bahasa Jepang di SMP Negeri 1 Ubud guru diharapkan mampu menemukan strategi pembelajaran yang tepat dan sesuai dengan kemampuan siswa, menguasai materi ajar, dan menemukan media pengajaran yang menarik agar peserta didik dapat memahami materi dengan cepat serta tidak mudah bosan dalam mengkuti pembelajaran. Dengan keterbatasan yang terdapat pada penelitian ini, diharapkan peneliti lain bisa menggali lebih dalam mengenai pembelajaran ekstrakurikuler bahasa Jepang di sekolah lain.

\section{Daftar Pustaka}

Anitah, Sri. 2009. Materi Pokok Strategi Pembelajaran SD. Jakarta: Universitas Muria Kudus.

Attle, Simon dan Bob Baker. 2007. "Cooperative Learning in a Competitive Environment:Classroom Applications", International Journal of Teaching and Learning in Higher Education, Volume 19, ISSN 1812-9129.

Cahyadiantari, Dwi dkk, "Strategi Guru Dalam Pembelajaran Membaca Teks Biografi Pada Siswa Kelas VIII SMP Negeri 2 Singaraja”. e-Journal Jurusan Pendidikan Bahasa dan Sastra Indonesia, Undiksha Volume : 7 No: 2.

Destiari, Santie. 2017. "Metode Dediscerta Meningkatkan Kemampuan Membaca Pemahaman Siswa", Jurnal Pendidikan dan Pengajaran Bahasa Jepang, Volume 2, Nomor 1, ISSN: 2528-5548.

Dewi, Ni Ketut Karunia Rini. 2015. Pofil Strategi Pembelajaran Bahasa Jepang Di SMA Negeri 1 Singaraja Tahun Ajaran 2014/2015. Skripsi (tidak diterbitkan). Singaraja: Undiksha

Direktorat Tenaga Pendidikan. 2008. Strategi Pembelajaran dan Pemilihannya. Jakarta.

Matsumoto, Isao.2007. Shokyuu o Oshieru. Tokyo: The Japan Foundation

Padmadewi, Ni Nyoman. 2012. Strategi Pembelajaran Bahasa. Singaraja : Undiksha

Putri, Ayu Sumina dkk. 2016. "Penerapan Pembelajaran Kooperatif Tipe Jigsaw Dalam Pendekatan Saintifik Dapat Meningkatkan Hasil Belajar Bahasa Indonesia. e-Journal PGSD Universitas Pendidikan Ganesha. Vol: 4 No: 1.

Roestiyah. 2001. Strategi Belajar Mengajar. Jakarta: Rineka Cipta.

Slameto, Belajar dan Faktor-Faktor yang Mempengaruhinya, Jakarta: PT. Rineka Cipta, 2003, Cet. Keempat

Yani, Damai. 2016. "Metode Audio-Lingual Method Dalam Pembelajaran Kaiwa", Jurnal Bahasa dan Pembelajaran Bahasa, Volume 10, ISSN 1979-0457.

Yastini, Luh Asri Januarti. 2015. Profil Pembelajaran Menulis Huruf Jepang Di SMA Negeri 4 Singaraja. Skripsi (Tidak diterbitkan) Singaraja : Undiksha 